\title{
EFEKTIVITAS MEDIA SOSIAL INSTAGRAM PARIWISATA JEMBER SEBAGAI MEDIA PROMOSI PARIWISATA ONLINE
}

\author{
Windy Ayu Lestari ${ }^{1}$, Ni Putu Eka Mahadewi ${ }^{2}$, Luh Gede Leli Kusuma Dewi ${ }^{3}$ \\ Email:windylestari537@gmail.com¹,eka.mahadewi23@gmail.com², leli_ipw@unud.ac.id ${ }^{3}$ \\ ${ }^{123}$ Program Studi Industri Perjalanan Wisata, Fakultas Pariwisata, Universitas Udayana
}

\begin{abstract}
Promotional activities can be effective if the promotional purpose is achieved. To find out how effective the promotional media, it is necessary to measure the effectiveness of the media. This study aims to find out the effectiveness of Instagram social media @pariwisatajember as an online tourism promotion media by using the EPIC model method. Measurement of promotion effectiveness using EPIC model method is done by calculating first the average value of empathy dimension, persuasion dimension, impact dimension, and communication dimension, the determine the EPIC rate to find out how effective the promotion. The technique of determining samples in this study using the accidental sampling method is as many as 98 respondents. Data collection techniques using observation, interviews, questionnaires, literature, studies, and documentation. Data analysis techniques use descriptive quantitative analysis techniques, validity tests, reliability tests, and EPIC model analysis. The result showed that the effectiveness of Instagram social media @pariwisatajember as an online tourism promotion media showed effective result this shown by the measurement of the average value of the four dimensions and epic rate that within the effective scale range, where each value obtained is in empathy dimension of 3,63 , persuasion dimension of 3,53 , impact dimension of 3,54 , communication dimension of 3,64 and EPIC rate of 3,58.
\end{abstract}

Abstrak: Kegiatan promosi dapat dikatakan efektif apabila tujuan dari promosi itu sendiri dapat tercapai. Untuk mengetahui seberapa efektif suatu media promosi, diperlukan pengukuran efektivitas terhadap media tersebut. Studi ini bertujuan untuk mengetahui efektivitas media sosialinstagram@pariwisatajember sebagai media promosi pariwisata online dengan menggunakan metode EPIC model. Pengukuran efektivitas promosi menggunakan metode EPIC model dilakukan dengan cara menghitung terlebih dahulu nilai rata-rata dimensi empathy, dimensi persuasion, dimensi impact dan dimensi communication, selanjutnya menentukan nilai EPIC rate untuk mengetahui seberapa efektif promosi yang dilakukan. Teknik penentuan sampel dalam studi ini menggunakan metode accidental sampling yaitu sebanyak 98 responden. Teknik pngumpulan data menggunakan observasi, wawancara, kuesioner, studi kepustakaan dan dokumentasi. Teknik analisis data menggunakan teknik analisis deskriptif kuantitatif, uji validitas, uji reliabilitas, dan analisis EPIC model. Hasil studi menunjukkan bahwa efektivitas media sosialinstagram @pariwisatajember sebagai media promosi pariwisata online menunjukkan hasil yang efektif. Hal ini ditunjukkan dari hasil pengukuran nilai rata-rata keempat dimensi dan nilai EPIC rate yang masuk dalam rentang skala efektif, dimana masing-masing nilai yang diperoleh yaitu pada dimensi empathy sebesar 3,63, dimensi persuasion sebesar 3,53, dimensi impact sebesar 3,54, dimensi communication sebesar 3,64 dan nilai EPIC rate sebesar 3,58.

Keywords: effectiveness, jember, promotion, instagram, epic model. 


\section{PENDAHULUAN}

Perkembangan pariwisata di Indonesia sekarang ini semakin pesat. Perkembangan pariwisata di Indonesia dapat terlihat dari semakin banyaknya destinasi wisata yang muncul. Hal ini tidak lepas dari diberlakukannya undang-undang No. 22 Tahun 1999 tentang Pemerintahan Daerah yang memberikan kebebasan dan kewenangan kepada daerah untuk mengatur dan memanfaatkan sumber daya yang dimiliki dengan maksimal untuk menghasilkan pendapatan bagi daerah dan memperkenalkan potensi wisata yang dimiliki. Untuk memperkenalkan potensi wisata yang ada di suatu daerah maka diperlukan kegiatan promosi yang efektif dari pihak terkait, baik dari pemerintah daerah maupun pengelola pariwisata setempat.

Kegiatan promosi dapat melalui media offline ataupun melalui media online. Melalui media offline, kegiatan promosi dilakukan dengan memanfaatkan media cetak dan elektronik, sedangkan promosi melalui media online dilakukan dengan memanfaatkan teknologi internet. Secara offline, promosi dilakukan dengan cara menyebar leaflet, brosur, memasarkan secara langsung, melalui radio, televisi dan lain sebagainya, sedangkan promosi secara online dapat dilakukan melalui media sosial, website, blog dan sejenisnya. Kegiatan promosi secara offline memiliki kelemahan yaitu banyak memakan biaya, sedangkan promosi dengan menggunakan media online memiliki beberapa keuntungan antara lain tidak memakan banyak biaya, informasi dapat tersebar luas, mudah diakses, dan tidak terbatas waktu ataupun wilayah. Utami (2011) dalam studinya menyebutkan bahwa dari kedua jenis media promosi tersebut, media online merupakan media yang sangat menjanjikan dalam mempromosikan suatu produk atau kawasan mengingat pesatnya perkembangan teknologi internet yang ada saat ini.

Berdasarkan Asosiasi Penyelenggara Jasa Internet Indonesia (APJII) tahun 2020, jumlah pengguna internet di Indonesia menunjukkan adanya peningkatan dalam kurun waktu lima tahun terakhir yaitu mulai tahun 2015-2019 dimana pada tahun 2015 jumlah tersebut mencapai 93,4 juta, tahun 2016 mencapai 132,7 juta, tahun 2017 mencapai 143,3 juta, tahun 2018 mencapai 171,1 juta, dan tahun 2019 mencapai 175 juta pengguna. Hal ini memperkuat alasan bagi pengusaha khususnya pengelola pariwisata untuk memanfaatkan media online sebagai sarana promosi untuk produk dan jasa mereka.

Promosi dengan media online dapat dilakukan melalui marketplace, website maupun media sosial. Dari beberapa jenis media tersebut, media sosial memiliki peluang besar sebagai media promosi online. Hal ini dikarenakan perkembangan penggunaan media sosial di Indonesia cukup tinggi. Menurut data Asosiasi Penyelenggara Jasa Internet Indonesia (APJII) menunjukkan bahwa dari 175 juta penduduk Indonesia yang menggunakan internet pada akhir tahun 2019, sebesar 97,4 persen banyak meluangkan waktunya untuk mengakses media sosial, dalam hal ini hampir seluruh pengguna internet di Indonesia menghabiskan waktunya untuk mengakses media sosial. Salah satu media sosial yang berpotensi untuk dijadikan sebagai media promosi online adalah instagram.

Instagram menempati urutan keempat sebagai media sosial yang sering digunakan pada tahun 2020 setelah youtube, whatsapp dan facebook, dengan persentase sebesar 79\% (Databoks katadata, 2020). Kini instagram telah berkembang sebagai media para pebisnis untuk mempromosikan produknya. Tren ini telah banyak digunakan oleh perusahaan di seluruh dunia, sebuah studi yang dilakukan oleh Simply Measured (dalam Mardalis dan Hastuti, 2018:53) mengungkapkan bahwa sebanyak $54 \%$ perusahaan dengan brand terkenal menggunakan instagram sebagai media promosi online. Hal tersebut membuka peluang besar bagi pengelola pariwisata dalam menggunakan instagram untuk sarana promosi pariwisata di masing-masing daerahnya, salah satunya yaitu Kabupaten Jember.

Kabupaten Jember merupakan sebuah wilayah yang berada diujung timur Pulau Jawa. Kabupaten Jember memiliki potensi wisata yang beragam, dilihat dari jenis daya tarik wisatanya menyajikan daya tarik wisata alam, budaya dan buatan. Menurut data dari Dinas Pariwisata dan Kebudayaan setempat menyebutkan bahwa Kabupaten Jember memiliki 65 daya tarik wisata baik wisata alam, wisata budaya, maupun wisata buatan. Daya tarik wisata alam di Kabupaten Jember diantaranya berupa pantai, air terjun, desa wisata, taman nasional serta agrowisata. Daya 
tarik wisata budaya diantaranya berupa situs sejarah dan beberapa event budaya salah satunya yaitu Jember Fashion Carnaval, sedangkan daya tarik wisata buatan berupa taman dan kolam pemandian.

Melihat potensi wisata yang dimiliki Kabupaten Jember tersebut, maka pemerintah Kabupaten Jember khususnya Dinas Pariwisata dan Kebudayaan Kabupaten Jember sedang gencar melaksanakan salah satu strategi pemasarannya yaitu dengan melaksanakan promosi pariwisata. Hal ini sesuai dengan tugas dan fungsi Dinas Pariwisata dan Kebudayaan Kabupaten Jember dalam peraturan Bupati Jember No. 41 tahun 2016 pasal (2) ayat (1) tentang Kedudukan, Susunan Organisasi, Tugas dan Fungsi serta Tata Kerja Dinas Pariwisata dan Kebudayaan Kabupaten Jember, yang menyatakan bahwa Dinas Pariwisata dan Kebudayaan Kabupaten Jember pada Bidang Pemasaran dan Kerjasama Pariwisata mempunyai salah satu tugas dan fungsi melaksanakan pengadaan kegiatan promosi pariwisata dan pemasaran pariwisata.

Dalam kurun waktu lima tahun terakhir pariwisata Kabupaten Jember telah mengalami perkembangan, hal ini dapat dilihat dari jumlah kunjungan wisatawan ke Kabupaten Jember yang mengalami peningkatan. Berdasarkan data dari Dinas Pariwisata dan Kebudayaan Kabupaten Jember tahun 2020 menunjukkan bahwa jumlah kunjungan wisatawan domestik maupun mancanegara pada tahun 2015 sebesar 1.055,794, tahun 2016 sebesar 1.442.475, tahun 2017 sebesar 1.459.407, tahun 2018 sebesar 1.460.019, dan tahun 2019 sebesar 1.527.897 dengan rata-rata persentase pertumbuhan sebesar $11,95 \%$, namun jumlah tersebut masih belum mencapai target kunjungan yang telah ditetapkan sebelumnya. Salah satu upaya untuk mencapai target kunjungan wisatawan di Kabupaten Jember yaitu dengan melaksanakan kegiatan promosi. Dalam hal ini, para stakeholder pariwisata di Kabupaten Jember memegang peranan penting untuk melakukan kegiatan promosi yang efektif, salah satunya yaitu Dinas Pariwisata dan Kebudayaan Kabupaten Jember.

Pihak Dinas Pariwisata dan Kebudayaan Kabupaten Jember saat ini telah memanfaatkan media online untuk mempromosikan pariwisata, salah satunya yaitu melalui media sosial instagram dengan nama akun @ pariwisatajember. Perkembangan teknologi internet, menuntut instansi tersebut memanfaatkan media online sebagai salah satu media untuk mempromosikan pariwisata di Jember. Hal ini bertujuan untuk mengikuti tren baru beriklan dan promosi dibidang pariwisata. Instagram@pariwisatajember dikelola langsung oleh Dinas Pariwisata dan Kebudayaan Kabupaten Jember pada Bidang Pemasaran dan Kerjasama Pariwisata. Tujuan dibuatnya instagram ini yaitu sebagai sarana promosi yang efektif untuk menarik minat wisatawan agar melakukan aktivitas wisata di Kabupaten Jember. Instagram @pariwisatajember merupakan akun resmi yang didalamnya memuat informasi mengenai pariwisata di Kabupaten Jember. Melalui instagram tersebut, Dinas Pariwisata dan Kebudayaan Kabupaten Jember mempromosikan potensi wisata mulai dari wisata alam, budaya, maupun buatan berupa foto dan video.

$\begin{array}{ccc}\text { Dalam mempromosikan } & \text { potensi } \\ \text { pariwisata } & \text { melalui } & \text { instagram }\end{array}$
@pariwisatajember ini diharapkan dapat menekan biaya promosi yang tinggi serta akan membuat sasaran promosi lebih efektif (kompas.com). Promosi dapat dikatakan efektif apabila tujuan dari promosi itu sendiri dapat tercapai. Secara umum, tujuan kegiatan promosi adalah untuk mempengaruhi konsumen agar mereka dapat menjadi kenal akan produk atau jasa yang ditawarkan oleh perusahaan kepada mereka kemudian mereka menjadi senang lalu membeli produk atau jasa tersebut (Indriyo Gitosutomo: 2008). Untuk mengetahui seberapa efektif suatu media promosi dalam mempromosikan suatu produk perlu adanya pengukuran efektivitas dari media tersebut.

Alasan yang mendasari perlunya melaksanakan pengukuran efektivitas sebuah media promosi antara lain adalah untuk menghindari kesalahan yang membawa konsekuensi kerugian baik dari segi waktu, tenaga, maupun finansial. Misalnya jika dari pengukuran efektivitas diketahui bahwa promosi tersebut tidak berhasil membujuk segmen konsumen yang ditargetkan, maka metode lain dapat segera dipertimbangkan. Alasan lain adalah untuk mencari strategi alternatif dalam pemasaran yang lebih baik. Misalnya dari studi ini, jika dari pengukuran efektivitas diketahui bahwa performa instagram@pariwisatajember dalam 
mempromosikan pariwisata jember yang dilakukan tidak lebih baik dari performa promosi pada media lainnya, maka Dinas Pariwisata dan Kebudayaan Kabupaten Jember dapat mencari strategi alternatif dalam promosi yang lebih baik. Oleh karena itu perlu adanya studi mengenai efektivitas media sosial instagram@pariwisatajember sebagai media promosi pariwisata online sehingga dapat menjadi tolak ukur efektif atau tidaknya media tersebut sebagai media promosi. Pengukuran efektivitas promosi diukur menggunakan metode EPIC model dengan empat dimensi kritis yaitu dimensi empathy, persuasion, impact, dan communication.

\section{METODE}

Studi ini dilakukan untuk mengukur tingkat efektivitas media sosial instagram @pariwisatajember sebagai media promosi pariwisata online, sehingga dapat menjadi tolak ukur efektif tidaknya instagram tersebut sebagai media promosi pariwisata secara online di Kabupaten Jember. Adapun variabel yang digunakan adalah variabel efektivitas promosi dengan metode EPIC Model yang terdiri dari empat indikator yaitu empathy, persuasion, impact dan communication. Empathy merupakan keadaan mental yang membuat seseorang mengidentifikasikan dirinya atau merasa dirinya pada keadaan, perasaan atau pikiran yang sama dengan orang atau kelompok lain, indikator empathy digunakan untuk mengukur apakah responden menyukai informasi yang ditampilkan di instagram @pariwisatajember. Persuasion adalah perubahan kepercayaan, sikap, dan keinginan berperilaku yang disebabkan satu komunikasi promosi, indikator persuasion digunakan untuk mengukur perubahan kepercayaan, sikap, dan keinginan berperilaku dari responden setelah melihat postingan yang ditampilkan di instagram@pariwisatajember. Impact berarti iklan dinilai apakah mampu menangkap perhatian wisatawan dan meningkatkan pengenalan merek atau tidak, indikator impact digunakan untuk mengukur tingkat pengetahuan responden mengenai pariwisata Jember melalui informasi yang ditampilkan di instagram@pariwisatajember, serta apakah postingan yang ditampilkan tersebut terlihat lebih menonjol daripada postingan instagram lain. Communication memberikan informasi tentang kemampuan wisatawan dalam mengingat pesan utama yang disampaikan, pemahaman wisatawan, serta kekuatan kesan yang ditinggalkan pesan tersebut. indikator communication digunakan untuk mengukur apakah informasi yang ditampilkan pada instagram tersebut mampu diingat, dipahami, dan dimengerti oleh reponden.

Teknik pengumpulan data yang digunakan dalam studi ini yaitu: 1) Observasi, melakukan pengamatan langsung pada instagram @pariwisatajember. 2) Wawancara, melakukan tanya jawab dengan admin instagram @ pariwisatajember sekaligus sebagai staf Dinas Pariwisata dan Kebudayaan Kabupaten Jember. 3) Kuesioner, teknik ini digunakan untuk memperoleh data dengan menyebarkan kuesioner online berbentuk google form kepada responden melalui direct message (DM). 4) Studi kepustakaan, mencari informasi dari berbagai buku atau literatur-literatur yang berkaitan dengan studi ini, dan 5) Dokumentasi, yaitu pengambilan gambar atau foto terkait studi yang dilakukan.

Teknik pengambilan sampel responden yang digunakan dalam studi ini adalah non probability sampling dengan prosedur accidental sampling. Accidental sampling adalah teknik penentuan responden berdasarkan kebetulan, yaitu konsumen yang secara kebetulan/incidental bertemu dengan peneliti dapat digunakan sebagai sampel, bila dipandang orang yang kebetulan ditemui itu cocok sebagai responden (Sugiyono, 2010). Responden dalam studi ini yaitu pengikut instagram@pariwisatajember yang pernah melihat postingan di instagram tersebut dan pernah melakukan kunjungan wisata ke Jember minimal satu kali. Penentuan jumlah responden menggunakan rumus slovin yaitu sebanyak 98 reponden.

Teknik analisis data dalam studi ini menggunakan teknik analisis deskriptif dengan pendekatan kuantitatif. Data hasil jawaban kuesioner skala likert dari responden selanjutnya dianalisis menggunakan metode EPIC model untuk mengetahui tingkat efektivitas promosi instagram @pariwisatajember.

\section{HASIL DAN PEMBAHASAN Gambaran Umum}

Kabupaten Jember merupakan bagian dari Provinsi Jawa Timur, terletak $\pm 200 \mathrm{~km}$ kearah timur dari Surabaya. Kabupaten Jember 
secara geografis terletak pada posisi $113^{\circ} 15^{\prime} 47^{\prime}$ ' sampai $114^{0} 02^{\prime} 35^{\prime}$ ' Bujur Timur dan $7^{0} 58^{\prime} 06^{\prime}$ " sampai $8^{0} 33$ " 44 " lintang selatan. Data dari Dinas Pariwisata dan Kebudayaan setempat menyebutkan bahwa Kabupaten Jember memiliki 65 daya tarik wisata baik itu wisata alam, wisata budaya, maupun wisata buatan. Melihat daya tarik wisata yang dimiliki Kabupaten Jember tersebut, maka para stakeholder pariwisata salah satunya pihak Dinas Pariwisata dan Kebudayaan Kabupaten Jember sedang gencar melaksanakan salah satu tugasnya yaitu melakukan kegiatan promosi. Hal ini sesuai dengan peraturan Bupati Jember No. 41 tahun 2016 pasal (2) ayat (1) yang menyatakan bahwa Dinas Pariwisata dan Kebudayaan Kabupaten Jember pada Bidang Pemasaran dan Kerjasama Pariwisata mempunyai salah satu tugas dan fungsi melaksanakan pengadaan kegiatan promosi pariwisata dan pemasaran pariwisata.

Perkembangan teknologi internet yang semakin pesat, menjadikan peluang sekaligus tantangan bagi instansi tersebut untuk memanfaatkan media online dalam mempromosikan pariwisata di Jember, salah satunya yaitu melalui instagram dengan nama akun@pariwisatajember yang berada dibawah pengelolaan Dinas Pariwisata dan Kebudayaan Kabupaten Jember pada Bidang Pemasaran dan Kerjasama Pariwisata. Alasan memilih instagram sebagai media promosi pariwisata oleh Dinas Pariwisata dan Kebudayaan Kabupaten Jember dikarenakan instagram diyakini dapat menjadi media yang efektif untuk mempromosikan potensi pariwisata yang ada di Kabupaten Jember. Selain itu terdapat pula keunggulan dari segi fitur pada instagram yang diyakini dapat menjadikan tampilan promosi lebih menarik.

Sejarah akun instagram @pariwisatajember ini dibuat pertama kali karena kesadaran pemerintah Kabupaten Jember khususnya pihak Dinas Pariwisata dan Kebudayaan Kabupaten Jember akan adanya perkembangan penggunaan teknologi internet di era revolusi industri 4.0. Hal ini menuntut instansi tersebut melakukan kegiatan promosi pariwisata secara online salah satunya melalui instagram.@pariwisatajember dibuat pada tanggal 22 Juni 2014, dengan tujuan untuk mempromosikan daya tarik wisata yang ada di Jember. Per 26 September 2020, @pariwisatajember memiliki pengikut aktif sebanyak 6.003. Akun instagram @pariwisatajember dikelola langsung oleh Dinas Pariwisata dan Kebudayaan Kabupaten Jember pada Bidang Pemasaran dan Kerjasama Pariwisata. Kegiatan promosi yang dilakukan yaitu memposting foto dan membuat instagram story terkait destinasi wisata dan juga jadwal event pariwisata yang akan berlangsung di Kabupaten Jember seperti BBJ, Jember Fashion Carnaval, festival pegon dan lain-lain. Adapun foto profil yang digunakan instagram @ pariwisatajember yaitu menggunakan brand pariwisata Jember.

Foto profil instagram @pariwisatajember menampilkan kutipan "Lovely Destination" sebagai tagline pariwisata Jember. Selain itu, pada bio juga ditampilkan kutipan "Naturally Jember" sebagai city slogan pariwisata Jember. Dari kedua kutipan tersebut memiliki makna yang dapat menggambarkan kondisi pariwisata Jember. City slogan "Naturally Jember" menggambarkan kondisi Jember yang masih alami, sementara tagline "Lovely Destination" mempunyai makna bahwa karena alam Jember yang masih alami maka destinasi-destinasi yang ada di Jember begitu elok dan menyenangkan. Pada logo tersebut juga terdapat gambar topeng yang mempresentasikan bahwa Jember dijuluki sebagai kota Fashion Carnaval dunia, hal ini dikarenakan Jember memiliki event carnaval tahunan yang sudah mendunia yaitu Jember Fashion Carnaval sebagai daya tarik wisata utama Kabupaten Jember.

\section{Karakteristik Responden}

Karakteristik responden dalam studi ini dilihat berdasarkan usia, jenis kelamin, daerah asal, tingkat pendidikan, jenis pekerjaan dan tingkat pendapatan. Berdasarkan hasil penyebaran kuesioner kepada 98 responden menunjukkan bahwa, karakteristik responden berdasarkan usia mayoritas adalah berusia $<25$ tahun dengan persentase sebesar 40,8\%, sedangkan responden dengan usia 25-37 tahun sebesar $36,7 \%$ dan usia $>37$ tahun sebesar $22,4 \%$. Hal tersebut disebabkan karena pengguna media sosial cenderung lebih banyak diakses oleh kalangan usia muda.

Berdasarkan jenis kelamin, mayoritas responden adalah perempuan dengan persentase sebesar $59,2 \%$ sedangkan jenis 
kelamin laki-laki sebanyak 40,8\%. Hal ini dikarenakan perempuan lebih senang bermain media sosial dibandingkan laki-laki. Hal ini didukung menurut Nrayung (2012) bahwa perempuan lebih menyukai dengan hal baru seperti dengan dunia maya sehingga mereka bisa menambah temannya meskipun hanya di dunia maya atau untuk berbelanja online. Berbeda dengan laki-laki lebih menyukai dengan hal yang lebih nyata untuk bersosialisasi secara langsung.

Responden berdasarkan daerah asal mayoritas berasal dari Jember dengan persentase sebesar 32,6\%, daerah asal Lumajang sebesar 24,5\%, Bondowoso sebesar $13,3 \%$, Gresik sebesar 11,2\%, Banyuwangi sebesar $9,2 \%$, Tulungagung sebesar $6,1 \%$ dan Pasuruan sebesar 3,1\%. Berdasarkan tingkat pendidikan responden mayoritas adalah SMA dengan persentase sebesar 33,7\%. Sedangkan tingkat pendidikan sarjana sebanyak 29,6\%, diploma sebanyak 27,6\% dan SMP memiliki persentase yang paling rendah yaitu $9,2 \%$. Hal ini berkaitan dengan usia responden yang masih muda, dimana pada usia tersebut cenderung lebih memiliki banyak waktu untuk mengakses media sosial.

Berdasarkan tingkat pendapatan responden yang paling banyak berada pada kategori $\quad 1.000 .000-2.500 .000$ dengan persentase sebesar $45,9 \%$, sedangkan pendapatan $>2.500 .000$ sebesar $38,8 \%$ dan pendapatan $<1.000 .00$ sebesar $15,3 \%$. Hal ini menunjukkan bahwa responden yang berstatus sebagai pelajar masih mendapatkan penghasilan dari uang saku yang diperoleh, sehingga masih belum memiliki pendapatan yang tinggi. Menurut Sumarwan (2011), pendidikan yang tinggi diasumsikan juga memiliki pendapatan yang tinggi.

Uji validitas digunakan untuk menguji atau mengukur sah atau tidaknya suatu kuesioner. Item kuesioner dinyatakan valid apabila masing-masing item tersebut memiliki taraf signifikansi $\alpha<0,05$ dan nilai $r$ hitung lebih besar dari nilai $r$ tabel. Nilai $r$ tabel dapat dilihat pada tabel $\mathrm{r}$ dengan ketentuan $\mathrm{df}=98$ dan sig $5 \%$, sehingga diperoleh nilai $r$ tabel sebesar 0,199 . Uji reliabilitas digunakan untuk menunjukkan konsistensi suatu alat pengukur didalam mengukur gejala yang sama. Suatu variabel dianggap reliabel jika nilai alphacronbach diatas 0,6 .
Berdasarkan uji validitas dan reliabilitas menggunakan program SPSS dengan jumlah sampel 98 responden, didapatkan hasil bahwa semua sub indikator memiliki $\mathrm{r}$ hitung lebih besar dari $r$ tabel dan nilai $\alpha<0,05$, maka $12 \mathrm{sub}$ indikator yang ada dinyatakan valid dan dapat melakukan tahapan berikutnya. Hasil pengujian reliabilitas dari 12 sub indikator memperoleh nilai Cronbach Alpha 0,681, yang artinya kuesioner reliabel karena memenuhi syarat nilai koefisien Cronbach Alpha $>0,6$.

\section{Efektivitas Media Sosial}

Untuk mengetahui tingkat efektivitas media sosial instagram@pariwisatajember sebagai media promosi pariwisata online dalam studi ini dilakukan dengan menggunakan metode EPIC model, yang bertujuan untuk mengetahui dampak komunikasi promosi terhadap responden yang telah melihat postingan informasi pariwisata yang ditampilkan di instagram tersebut.

Pengukuran tingkat efektivitas dilakukan dengan menganalisa hasil jawaban responden terhadap pernyataan kuesioner yang telah diberikan dengan menggunakan metode EPIC model. Tahapan analisis EPIC model yaitu diketahui terlebih dahulu analisis tabulasi sederhana, kemudian menentukan skor ratarata dari keempat dimensi yaitu dimensi empathy, dimensi persuasion, dimensi impact dan dimensi communication. Setelah diketahui skor rata-rata dari masing-masing dimensi, langkah selanjutnya yaitu menghitung tingkat efektivitas instagram@pariwisatajember dengan menggunakan rumus EPIC rate, sehingga akan diketahui posisi efektivitas instagram tersebut sebagai media promosi pariwisata online di Kabupaten Jember. Studi ini dilakukan untuk mendapatkan nilai rata-rata pada dimensi empathy, dimensi persuasion, dimensi impact, dimensi communication dan nilai EPIC rate dari bentuk promosi melalui instagram yang telah dilaksanakan oleh Dinas Pariwisata dan Kebudayaan Kabupaten Jember.

\section{Analisis Dimensi Empathy}

Berdasarkan hasil analisis tampak bahwa: pernyataan pertama dan kedua pada dimensi empathy yaitu "Informasi yang ditampilkan di instagram@pariwisatajember dapat menarik perhatian saya" dan "Saya menyukai informasi yang ditampilkan di instagram @pariwisatajember" mempunyai 
skor rata-rata yang sama yaitu 3,65. Hal ini menunjukkan bahwa responden menyukai informasi pariwisata yang ditampilkan di instagram@pariwisatajember sehingga mampu menarik perhatian mereka. Pernyataan ketiga pada dimensi empathy yaitu "Informasi pariwisata yang ditampilkan sangat bagus menjadikan saya ingin melihat postingan terbaru di instagram @pariwisatajember" mempunyai skor rata-rata 3,60. Hal ini menunjukkan bahwa responden memiliki ketertarikan yang mendalam dan muncul rasa ingin tahu yang lebih terhadap informasi yang ditampilkandi instagram@pariwisatajember.

Hasil analisis efektivitas instagram @ pariwisatajember sebagai media promosi pariwisata online dilihat dari dimensi empathy termasuk dalam rentang skala efektif, dengan perolehan skor rata-rata 3,63. Hal ini menunjukkan bahwa kegiatan promosi pariwisata Jember melalui instagram @pariwisatajember mampu memberikan informasi ataupun pesan yang menarik sehingga disukai oleh responden serta menumbuhkan rasa ingin tahu yang lebih terhadap informasi yang ditampilkan.

\section{Analisis Dimensi Persuasion}

Berdasarkan hasil analisis menunjukkan bahwa: pernyataan pertama pada dimensi persuasion yaitu "Setelah melihat postingan di instagram@pariwisatajember membuat saya ingin mengetahui tentang pariwisata Jember lebih jauh" mempunyai skor rata-rata sebesar 3,47. Hal ini menunjukkan bahwa tampilan informasi pariwisata di instagram @pariwisatajember mampu membuat responden tertarik dan ingin mengetahui lebih jauh tentang pariwisata Jember. Pernyataan kedua yaitu "Setelah melihat postingan di instagram@pariwisatajember membuat saya ingin mengunjungi Jember" mempunyai skor rata-rata 3,52. Hal ini menunjukkan bahwa tampilan informasi pariwisata di instagram @pariwisatajember mampu membuat responden memiliki niat untuk melakukan kunjungan ke Jember. Pernyataan ketiga yaitu "Setelah melihat postingan di instagram @pariwisatajember membuat saya ingin membagikan postingan tersebut kepada teman/keluarga/orang lain" mempunyai skor rata-rata 3,60. Hal ini menunjukkan bahwa tampilan informasi pariwisata di instagram @pariwisatajember mampu membuat responden ingin untuk membagikan informasi tersebut kepada teman/keluarga/orang lain.

Hasil analisis efektivitas media sosial instagram@pariwisatajember sebagai media promosi pariwisata online dilihat dari dimensi persuasion termasuk dalam rentang skala efektif, dengan perolehan skor rata-rata 3,53. Hal ini menunjukkan bahwa kegiatan promosi pariwisata Jember melalui instagram @pariwisatajember mampu membuat responden tertarik terhadap informasi yang ditampilkan, menumbuhkan niat untuk berkunjung, serta membuat mereka ingin menyebarkan informasi tersebut kepada teman/keluarga/oran lain.

\section{Analisis Dimensi Impact}

Berdasarkan hasil analisis menunjukkan bahwa: pernyataan pertama pada dimensi impact yaitu "Saya mengetahui informasi daya tarik wisata yang ada di Jember melalui instagram @pariwisatajember" mempunyai skor rata-rata 3,59. Hal ini menunjukkan bahwa tampilan informasi pariwisata di instagram @pariwisatajember mampu menambah pengetahuan responden tentang daya tarik wisata yang ada di Jember. Pernyataan kedua yaitu "Saya mengetahui informasi tempat wisata menarik yang ada di Jember melalui instagram @pariwisatajember" mempunyai skor rata-rata 3,53. Hal ini menunjukkan bahwa tampilan informasi pariwisata di instagram @pariwisatajember mampu membuat responden mengetahui tempat wisata yang menarik di Jember. Pernyataan ketiga yaitu "Saya melihat postingan di instagram @ pariwisatajember lebih kreatif daripada postingan di instagram lain" mempunyai skor rata-rata 3,51. Hal ini menunjukkan bahwa tampilan informasi pariwisata di instagram @pariwisatajember terlihat lebih menarik dan kreatif bagi responden.

Hasil analisis efektivitas media sosial instagram@pariwisatajember sebagai media promosi pariwisata online dilihat dari dimensi impact termasuk dalam rentang skala efektif, dengan perolehan skor rata-rata 3.54. Hal ini menunjukkan bahwa kegiatan promosi pariwisata Jember melalui instagram @pariwisatajember mampu memberikan dampak terhadap pengetahuan dan pemahaman bagi responden tentang pariwisata yang ada di Jember. 


\section{Analisis Dimensi Communication}

Berdasarkan hasil analisis menunjukkan bahwa: pernyataan pertama pada dimensi communication yaitu "Informasi yang ditampilkandi instagram@pariwisatajember sangat jelas" mempunyai skor rata-rata 3,67. Hal ini menunjukkan bahwa tampilkan informasi pariwisata di instagram @pariwisatajember memberikan informasi yang jelas mulai dari deskripsi postingan maupun dari segi foto dan video yang ditampilan sehingga dapat dimengerti oleh responden. Pernyataan kedua yaitu "Informasi yang ditampilkan di instagram @pariwisatajember mudah untuk dipahami mempunyai skor rata-rata 3,61. Hal ini menunjukkan bahwa tampilan informasi pariwisata di instagram@pariwisatajember mampu mengkomunikasikan pesannya dengan baik sehingga dapat dengan mudah dipahami oleh responden. Pernyataan ketiga yaitu "Adanya slogan "Naturally Jember, Lovely Destination" pada bio instagram @pariwisatajember, membuat saya dapat mengingat pariwisata Jember yang masih alami" mempunyai skor rata-rata 3,63. Hal ini menunjukkan bahwa tampilan informasi mengenai slogan pariwisata Jember pada bio instagram@pariwisatajember mampu meninggalkan kesan bagi responden.

Hasil analisis efektivitas media sosial instagram@pariwisatajember sebagai media promosi pariwisata online dilihat dari dimensi communication termasuk dalam rentang skala efektif, dengan perolehan skor rata-rata 3,64. Hal ini menunjukkan bahwa kegiatan promosi pariwisata Jember melalui instagram @pariwisatajember mampu mengkomunikasikan pesannya dengan baik kepada responden sehingga mudah untuk dimengerti, dipahami dan dapat memberikan kesan.

\section{Analisis EPIC Rate}

Dalam analisis EPIC rate, dilakukan dengan keempat nilai rata-rata dimensi tersebut dijumlahkan kemudian dibagi untuk mendapatkan nilai EPIC Rate, sehingga akan diketahui tingkat efektivitas media sosial instagram@pariwisatajember sebagai media promosi pariwisata online. Berdasarkan perhitungan skor rata-rata dari keempat dimensi EPIC, diperoleh nilai EPIC rate sebesar 3,58. Jika dikaitkan dengan skala penilaian termasuk dalam kategori efektif. Hal ini memperlihatkan bahwa penggunaan instagram @pariwisatajember sebagai media promosi pariwisata online sudah efektif serta dapat mengkomunikasikan informasi dengan baik kepada responden. Berikut hasil grafik efektivitas media sosial instagram @pariwisatajember sebagai media promosi pariwisata online dengan menggunakan metode EPIC Model.

\section{SIMPULAN DAN SARAN Simpulan}

Hasil pengukuran efektivitas media sosialinstagram@pariwisatajember sebagai media promosi pariwisata online dengan metode EPIC Model, menunjukkan bahwa promosi yang dilakukan dinilai efektif dengan perolehan skor EPIC rate sebesar 3,58. Hal ini menunjukkan bahwa penggunaan media sosial instagram@pariwisatajember sebagai media promosi pariwisata online sudah dapat mengkomunikasikan informasi dengan baik kepada responden. Hasil pengukuran pada keempat dimensi juga menunjukkan hasil yang efektif, dimana skor rata-rata yang diperoleh pada dimensi empathy sebesar 3,63, skor ratarata pada dimensi persuasion sebesar 3,53, skor rata-rata pada dimensi impact sebesar 3,54 dan skor rata-rata pada dimensi communication sebesar 3,64.

\section{Saran}

Pihak Dinas Pariwisata dan Kebudayaan Kabupaten Jember sebaiknya dalam memposting informasi pariwisata baik yang berbentuk video maupun foto di instagram @pariwisatajember dapat menambahkan caption yang lebih persuasif. Hal ini bertujuan agar tampilan promosi mampu mendapat perhatian, minat, dan keinginan bagi wisatawan untuk segera mengunjungi daya tarik wisata di Kabupaten Jember, mengingat hasil pengukuran efektivitas pada dimensi persuasion memiliki skor paling rendah dari dimensi lain.

Pihak Dinas Pariwisata dan Kebudayaan Kabupaten Jember sebaiknya juga harus mempertimbangkan kegiatan promosi melalui media sosial lain selain instagram seperti youtube, twitter, dan media sosial lainnya. Hal ini bertujuan agar lebih mengkomunikasikan produk wisata kepada wisatawan secara menyeluruh. 
Disarankan bagi peneliti selanjutnya agar meneliti tentang efektivitas media sosial instagram@pariwisatajember sebagai media promosi online terhadap keputusan berkunjung wisatawan di Kabupaten Jember, hal ini dikarenakan bahwa dalam studi ini sebatas mengukur tingkat efektivitas media promosi dengan metode EPIC Model, dimana metode tersebut hanya mengukur tingkat minat dan kesukaan responden terhadap informasi yang ditampilkan. 


\section{Kepustakaan}

Apjii.or.id. 2019. Asosiasi Penyelenggara JasaInternetIndonesia(https://www.apjii .or.id.contentAsosiasiPenyelenggaraJasa InternetIndonesisa-apjii (Diakses pada 30 Mei 2020).

Dinas Pariwisata dan Kebudayaan Kabupaten Jember. Jumlah Kunjungan Wisatawan Domestik dan Mancanegara 2015-2019. Dinas Pariwisata dan Kebudayaan Kabupaten Jember. Jember.

Gitosudarmo, Indriyono, 2008, Manajemen Pemasaran, Yogyakarta: Penerbit: BPFE.

Jayani,D.H.2020.https://databoks.katadata.co.i $\mathrm{d} /$ datapublish/2020/02/26/10-mediasosial-yang-paling-sering-digunakan-di indonesia (diakses pada 30 Mei 2020).

Mardalis, ahmad dan Hastuti Ana Putri.2018. Pemanfaatan Media Sosial Untuk Membangun Kepercayaan Merk. Jurnal. Universitas Muhammadiyah Surakarta.

Nrayung, R. 2012. Perilaku Pemanfaatan Situs Jejaring Sosial (Facebook) di SMAN2 Suarabaya. Skripsi.

Peraturan Bupati Jember No. 41 Tahun 2016 tentang Kedudukan, Susuna Organisasi, Tugas dan Fungsi serta Tata Kerja Dinas Pariwisata dan Kebudayaan Kabupaten Jember.

Sugiyono. 2010. Metode Penelitian Pendidikan Pendekatan Kuantitatif, Kualitatif, dan $R \& D$. Bandung. Alfabeta.

Sumarwan U.2011. Perilaku Konsumen: Teori dan Penerapannya dalam Pemasaran. Jakarta: Ghalia Indonesia.

Undang-undang No.22 Tahun 1999 tentang Pemerintahan Daerah.

Utami A. 2011. Analisis Strategi Promosi Online PT Media Indonesia. Skripsi. Bogor. Institut Pertanian Bogor. 